\title{
Experimental study of the fine particles effect on the shear strength of tuff zeolites
}

\section{Estudio experimental sobre el efecto de la fracción fina en la resistencia al corte de zeolitas de tobas}

Felipe A. Villalobos (Main and Corresponding Author)

Laboratorio de Geomateriales, Departamento de Ingeniería Civil, Facultad de Ingeniería, Universidad Católica de la Santísima Concepción

Campus San Andrés, Casilla 297, Concepción (Chile)

avillalobos@ucsc.cl

\section{Eladio A. Leiva}

Constructora Lancuyen

Cochrane 635, piso 15, of. 1503, Torre A, Concepción (Chile)

eleiva@lancuyen.cl

\section{Óscar Jerez}

Instituto de Geología Económica Aplicada GEA, Universidad de Concepción

Casilla 160-C Concepción (Chile)

ojerez@udec.cl

\section{Mauro E. Poblete}

Masgeotecnia

Alonso Ovalle 62, casa 2, Lomas de San Andrés, Concepción (Chile)

mpoblete@me.cl

\section{Manuscript Code: 729}

Date of Acceptance/Reception: 05.04.2018/19.01.2016

DOI: $10.7764 /$ RDLC.17.1.23

\begin{abstract}
The effect of fine particles on the zeolite shear strength is assessed for possible construction applications. A brief geological description of the zeolite is presented. Three groups of zeolite samples were prepared, namely a coarse material with no fines, a finer material with $3 \%$ of silt and a silty material with $15 \%$ of clay. Results from standard classification, compaction and compressibility tests are shown and explained. It was found that due to the low specific gravity, low values of density were obtained in compaction tests. Additionally, shear strength tests were performed, resulting in different response in terms of shear stress and horizontal and vertical displacements. The coarse zeolite followed a similar friction-dilation response as in feldspathic and quartz sands. However, addition of $3 \%$ of fines reduced significantly the zeolite shear strength. Furthermore, the finest material was tested under two different displacement rates, reflecting also marked differences in shear strength and stiffness.
\end{abstract}

Key words: tuff zeolite, shear strength, rate effect, fine particles, direct shear test.

Resumen

Se estudia el efecto de los finos en la resistencia al corte de una zeolita para su posible uso en construcción. Se presenta una breve descripción geológica de la zeolita. Tres grupos de muestras de zeolita fueron preparadas: material grueso sin finos, con $3 \%$ de limo y con $15 \%$ de arcilla. Se muestran y explican los resultados de ensayos de clasificación, compactación y compresibilidad normalizados. Debido a la baja gravedad específica se obtuvieron bajos valores de densidad en ensayos de compactación. Se realizaron ensayos de resistencia al corte, resultando en respuestas diferentes de tensión de corte y desplazamientos horizontal y vertical. La zeolita gruesa respondió en fricción-dilatación de forma similar que arenas cuarzosas y feldespáticas. Sin embargo, la incorporación de 3\% de finos redujo significativamente la resistencia al corte de la zeolita. El material limoarcilloso fue ensayado bajo dos velocidades, reflejando también una marcada diferencia en resistencia al corte y rigidez.

Palabras clave: zeolita de toba; resistencia al corte; efecto de velocidad; partículas finas; ensayo de corte directo.

\section{Introduction and description of the problem}

Zeolites belong to the chemical group of hydrated aluminosilicates of Sodium, Calcium, Magnesium, Potassium and other alkaline minerals, whose formation is attributable to pyroclastic deposits. Zeolite has a tecto-silicate 3D structure (the 4 oxygens of $\mathrm{SiO}_{4}^{-4}$ tetrahedra are shared with other tetrahedra) and in contrast to other tecto-silicates such as feldspar and quartz, the zeolite structure is remarkably open. Zeolites have voids like tunnels that can loosely hold water molecules. These tunnels can adsorb molecules smaller than the tunnel's diameter, for this reason, zeolites can act as molecular filters (e.g. Mier, Callejas, Gehr, Cisneros \& Alvarez, 2001; Yukselen, 2010). The zeolite is a non-metallic 
mineral utilized commonly as adsorbent, detergent, in refrigeration systems, pharmaceutical products, industrial processes, fertiliser and in paper products, among other applications. Owing to the high cationic interchange, it can be used as adsorbent to remove pollutants in contaminated water (e.g. Kayabali \& Kezer, 1998). Zeolite has also been used to improve the performance of concrete (e.g. Janotka \& Mojumdar, 2003; de la Cruz, del Campo \& Colorado, 2015; Raggiotti, Positieri, Locati, Murra \& Marfil, 2015; Ramirez, Chagoyén \& Martirena, 2017) and asphalt (e.g. Alonso, Tejeda, Moreno, Rubio \& Medel, 2013). Hong, Shackelford \& Malusis (2012) have studied the effect of adding zeolite in soil-bentonite mix as a cut-off wall against seepage with pollutants migration. However, the inclusion of zeolite did not increase the stiffness nor reduce the permeability of the soil-bentonite mix. In an attempt to reduce the amount of Portland cement for stabilizing clays, Jegandan, Liska, Osman \& Al-Tabbaa (2010) have found that adding between 10 and $15 \%$ of zeolite as cement replacement an optimum unconfined compressive strength UCS was reached, because UCS increased up to $36 \%$. They also found that the permeability reduced up to one order of magnitude when the above optimum amount of zeolite was added.

However, few studies have been focused on the shear strength in geotechnical applications of zeolite when compared with concrete, chemical or environmental applications. Yukselen (2010) shows results of geotechnical characterization of two zeolite samples from Turkey as a material for embankments and landfills. She obtained high values of shear strength under a slow displacement rate from direct shear tests and also mentioned the scarce number of zeolite shear strength studies. She could compare her results of cohesion and angle of friction only with those from a Turkish zeolite too by Kayabali (1997), although no plots are shown in this work since it was mainly focused on the effect of bentonite on the zeolite permeability.

Responding to the need to extend the data base of zeolite geotechnical characterization and in particular zeolite shear strength, this work aims to assess the effect of fine material on the shear strength behaviour of zeolite. This work presents the analysis of results of grain size analyses, mineral content, compaction and shear strength of natural zeolite samples from the Andes Mountains in Chile. This study may be useful for constructions in civil and mining projects involving geotechnical engineering applications such as road base or subbase, infilling material for soil improvement or backfill in retaining walls. Although none of these particular applications are pursued in this work.

\section{Geology and chemical composition state of the knowledge}

In Chile, the presence of zeolitic geological formations is due mainly to the volcanic nature of the Andes Mountains. Zeolite samples were extracted from a quarry in Quinamavida in the Colbun Province, Maule Region, Chile (3548'S $\left.71^{\circ} 26^{\prime} \mathrm{W}\right)$. In this area there are outcrops of volcanic rocks which belong to the Colbun Formation in the Precordillera, where lavas and andesitic and pyroclastic Breccia with inter-layering of tuffs, sandstones and mudstones, can be found (Karzulovic, Hauser \& Vergara, 1979). In the quarry, the volcaniclastic unit is made mainly of tuffs, deposited after wind and water transport by the pyroclastic material when intense volcanic activity took place in the volcanoes Nevados de Longaví, Descavezado Grande and Chico and Peteroa-Planchón. These tuffs are composed mainly of quartz, plagioclase and a group of zeolites and clays, which are the result of the rock formation. The zeolite is from the mordenite, cliptonite and heulandite types and the rock formation was due to compaction and consolidation of sediments, where the latter involves water release draining to permeable materials.

Figure 1 shows results of X-ray diffraction tests of a Quinamavida tuff sample, where it can be observed the significant presence of mordenite and clinoptilolite, but less heulandite. The chemical composition of this sample can be divided as 63 to $66 \%$ of $\mathrm{SiO}_{2}, 10$ to $13 \%$ of $\mathrm{Al}_{2} \mathrm{O}_{3}, 1$ to $4 \%$ of $\mathrm{Fe}_{2} \mathrm{O}_{3}, 2$ to $3 \% \mathrm{CaO}$, below $2 \%$ of $\mathrm{Na}_{2} \mathrm{O}, \mathrm{K}_{2} \mathrm{O}$ and $\mathrm{MgO}$, and less than $0.5 \%$ of $\mathrm{MnO}, \mathrm{TiO}_{2}$ and $\mathrm{P}_{2} \mathrm{O}_{5}$.

Measurements of pH according to ASTM D 4972 (2013) resulted in values between 4.9 and 5.1 for temperatures between 30.8 and $27^{\circ} \mathrm{C}$, respectively. These high temperatures were caused by reactions of the zeolite with water. For more geological and chemical details of the zeolite from the Quinamavida tuffs, the reader should refer to Bascuñán (2005). 


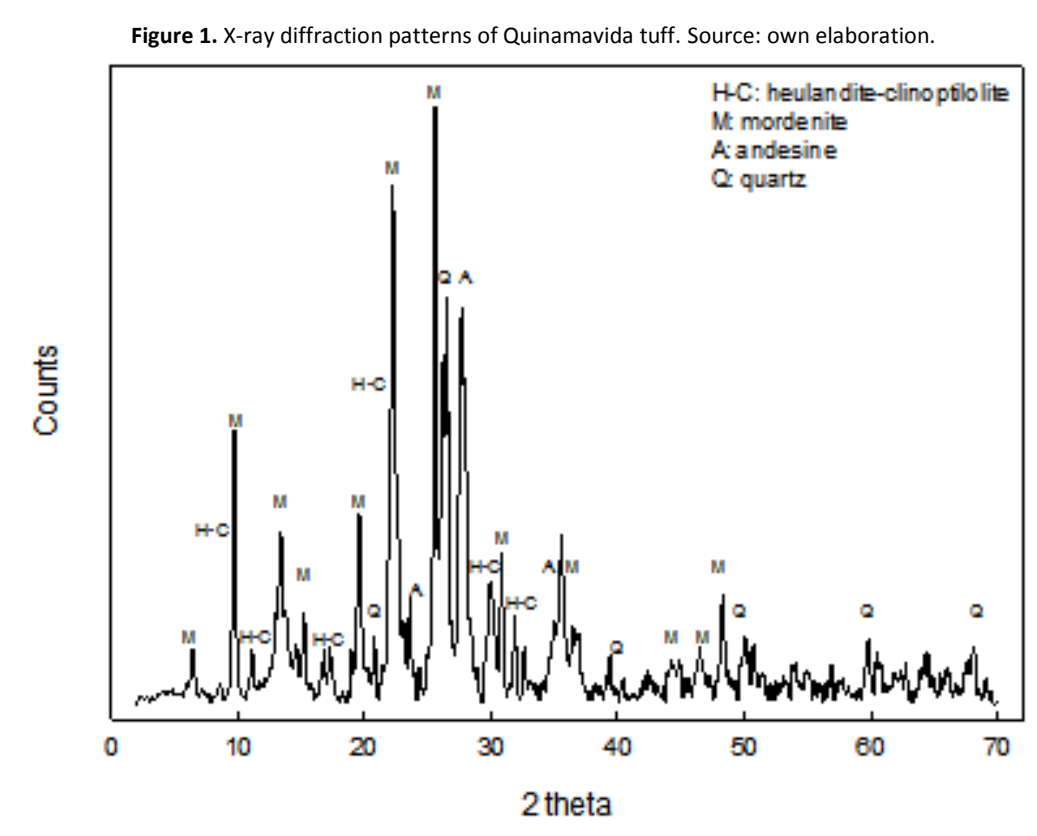

Materials and methods

\section{Grain size distribution}

An amount of $120 \mathrm{~kg}$ of ground tuff was purchased from the quarry in Quinamavida with particle sizes between 2 and $5 \mathrm{~mm}$. This material was additionally ground to obtain coarse zeolite CS (Coarse Sand type zeolite), fine zeolite FS (Fine Sand type zeolite) and silty zeolite S (Silt type zeolite). The sandy zeolite classifies as SP according to the USCS system (ASTM D 2487, 2011), i.e., uniformly distributed grains of sand. For the silty zeolite, plasticity tests are needed for a USCS classification, which is presented later on. The representative size distribution curves of the three samples are shown in Figure 2, where particles larger than $0.075 \mathrm{~mm}$ were passed through sieves in accordance with ASTM D 422 (2007). Hydrometer and laser tests were carried out for smaller particles. For the former sedimentation tests according to ASTM D 422 (2007) were carried out and for the latter a Fritsch Analysette 22 laser particle sizer device was used. For the finest zeolite sample, it can be observed in Figure 2 that there are $85 \%$ of silt and $15 \%$ of clay. The values of characteristic particle diameters and uniformity and curvature coefficients $\left(C_{u}, C_{c}\right)$ are coalesced in Table 1 . In addition of classification, values of $d_{10}$ can for instance be used for estimating the coefficient of permeability.

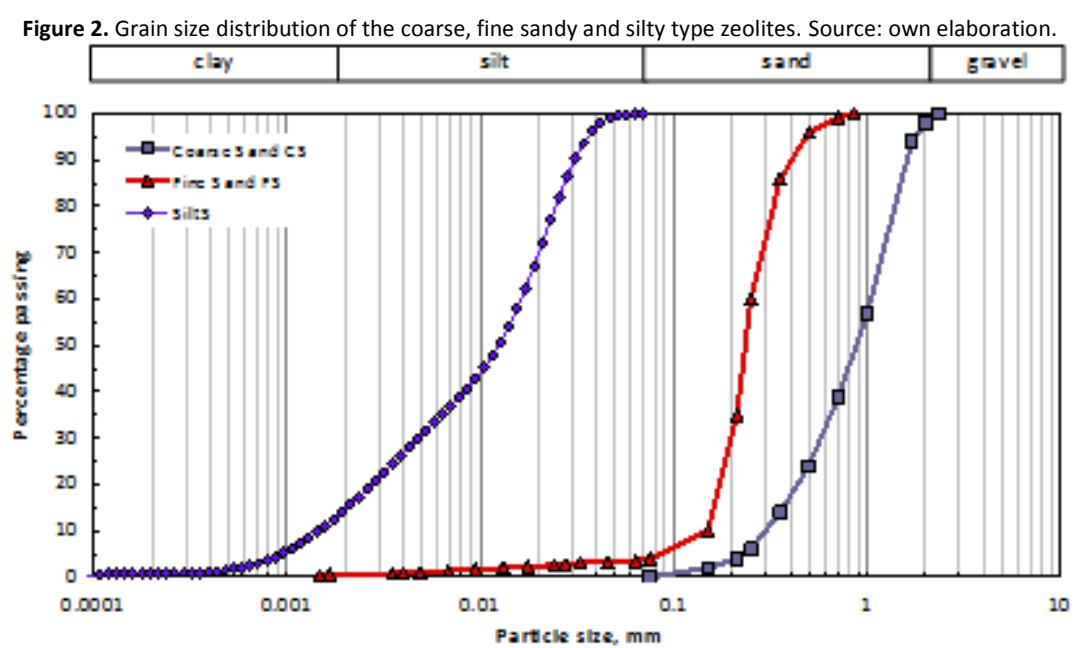

Table 1. Characteristic particle diameters and coefficients of grain size distribution curve shapes. Source: own elaboration.

\begin{tabular}{lccccccc}
\hline & $d_{\text {max }}, \mathrm{mm}$ & $d_{60}, \mathrm{~mm}$ & $d_{50, \mathrm{~mm}}$ & $d_{30, \mathrm{~mm}}$ & $d_{10}, \mathrm{~mm}$ & $C_{u}$ & $C_{c}$ \\
\hline $\mathrm{CS}$ & 2.4 & 1.04 & 0.88 & 0.58 & 0.30 & 3.47 & 1.08 \\
FS & 0.85 & 0.25 & 0.23 & 0.20 & 0.15 & 1.67 & 1.07 \\
$\mathrm{~S}$ & 0.07 & 0.016 & 0.012 & 0.0047 & 0.0015 & 10.7 & 0.92 \\
\hline
\end{tabular}




\section{Plasticity}

The Atterberg limits were determined for the zeolite finer than $0.075 \mathrm{~mm}$ as stated in ASTM D 4318 (2010). The plastic limit was determined in 18 remoulding by rolling tests, resulting in a plastic limit PL $=35.25 \% \pm 0.66 \%$ (mean \pm standard deviation). The liquid limit LL was determined in 21 tests using a standard Casagrande spoon, resulting in $\mathrm{LL}=69.50 \% \pm$ 1.47\%. In addition, 17 fall cone tests were performed following BS 1377 (1990), resulting in $L L=64.74 \% \pm 1.54 \%$. The results of Casagrande spoon and fall cone tests are plotted in Figure 3. The cone used has a $30^{\circ}$ tip angle, $80 \mathrm{~g}$ of weight and LL is determined for a $20 \mathrm{~mm}$ cone penetration. This difference in LL is similar to that reported by Leroueil \& Le Bihan (1996) for Canadian soils, namely LL $=70 \%$ using the spoon and $66.5 \%$ using the cone. They also mentioned other studies showing similar differences for both types of tests. Therefore, the zeolite tested has comparable different values of $L L$ from both type of tests. This difference can be attributable to different friction effects between the spoon and the soil and the cone and the soil. On one side, in the Casagrande spoon test, percussive blows are applied to a sample divided in two little slopes. The number of blows required to cause the contact between both slopes divided by a predefined groove distance, is measured. On the other side, the failure mechanism in the fall cone tests corresponds to a rapid punching. Finally, the average plastic index is $\mathrm{PI}=34.25 \%$ and $29.49 \%$ for the spoon and cone, respectively. According to these results the finer sand zeolite classifies as a silty sand SM and the finest silty zeolite as a high plasticity silt $\mathrm{MH}$, although close to the $\mathrm{A}$ line, the limit with high plasticity clay.
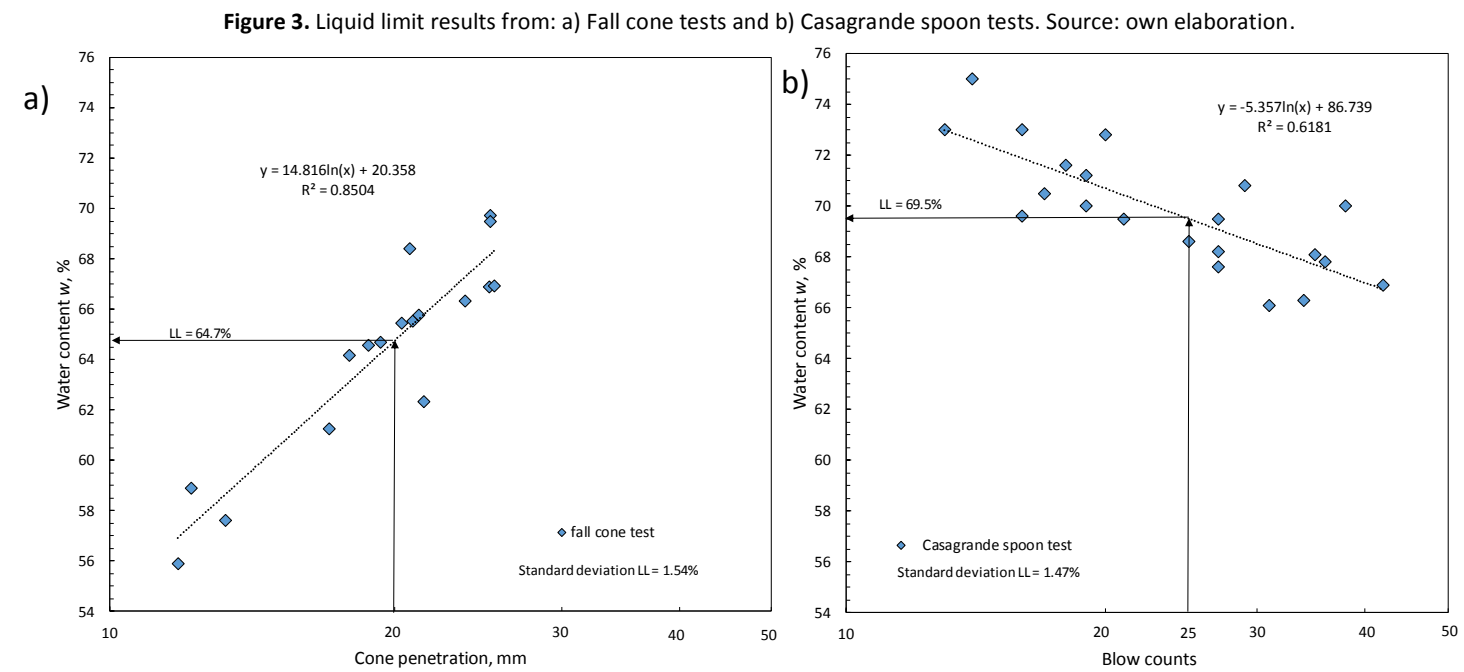

\section{Compaction and specific gravity}

Vibration and funnel pouring tests were carried out to determine the compaction capacity of the coarse zeolite. From the former, according to ASTM D 4253 (2006), the minimum void ratio $e_{\min }$ and consequently the maximum dry unit weight $\gamma_{\text {dmax }}$, are obtained; and from the latter, according to ASTM D 4254 (2006), the maximum void ratio $e_{\max }$ and minimum unit weight $\gamma_{d \min }$, are obtained. Table 2 shows the values of these parameters. It is worth noticing the low values of the dry unit weight, which can be explained by the following test results.

Table 2. Coarse zeolite parameters of maximum and minimum density tests. Source: own elaboration.
\begin{tabular}{cccc}
\hline$e_{\min }$ & $e_{\max }$ & $\gamma_{d \max }, \mathrm{kN} / \mathrm{m}^{3}$ & $\gamma_{d \min }, \mathrm{kN} / \mathrm{m}^{3}$ \\
\hline 1.02 & 1.64 & 10.6 & 8.1 \\
\hline
\end{tabular}

According to ASTM D 854 (2014) the pycnometer test allows the determination of the specific gravity of the zeolite, which resulted in $G_{s}=2.18$. Note that this low value of $G_{s}$, is even lower than other volcanic ash materials such as ignimbrite which have in average values of $G_{s}$ around 2.3 and 2.5. For instance, Canpolat, Yılmaz, Köse, Sümer \& Yurdusev (2004) report a $G_{s}$ value of 2.19 for natural zeolites from Turkey. Therefore, the low dry unit weight values obtained above are the result of the significantly low specific gravity value. Materials with low $G_{s}$ values can be useful as backfill in retaining structures since they apply less lateral earth pressures.

As specified in ASTM D 1557 (2012), modified Proctor tests were undertaken for samples with finer zeolite particles using an automatic equipment which avoids the operator energy variation when doing manually. The automatic equipment applies clockwise regular 30 blows/min. However, for the silty zeolite the hammer of this equipment stuck 
sometimes due to the sample high plasticity, altering the blow count, hence manual tests were carried out instead in these particular cases. Figure 4 shows the compaction curves, where for the fine zeolite the maximum dry unit weight $\gamma_{d \max }$ is $11.6 \mathrm{kN} / \mathrm{m}^{3}$ for an optimum water content $w_{\text {opt }}$ of $32 \%$ and a saturation $S$ of approximately $85 \%$. For the silty zeolite $\gamma_{d \max }=12.5 \mathrm{kN} / \mathrm{m}^{3}, w_{\text {opt }}=37.5 \%$ and $S=96 \%$. Note that the finest zeolite has a higher $\gamma_{d \max }$ and $w_{\text {opt }}$ values than those for the fine sand type zeolite and that these $\gamma_{d \max }$ values are larger than those for the coarse zeolite tested using vibration tests. This trend has also been found by Ören \& Kaya (2014) for Turkish fine and coarse zeolite in standard Proctor tests $\left(\gamma_{d \max }=11.5\right.$ and $10.2 \mathrm{kN} / \mathrm{m}^{3} ; w_{o p t}=45$ and $38 \%$, respectively). This may be explained by the fact that for the same material finer fractions tend to arrange in a more packed form than that for coarse fractions and hence higher densities can be obtained.

Figure 4. Compaction curves of fine sand and silt type zeolite samples. Source: own elaboration.

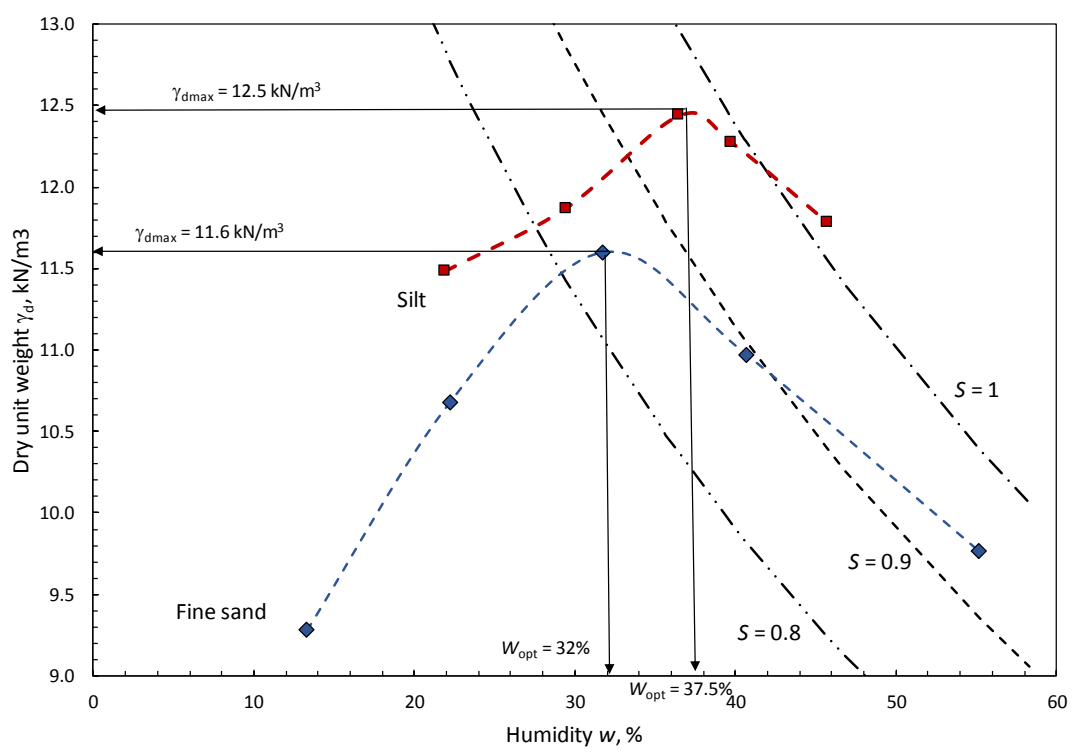

\section{Compressibility}

Due to the importance of knowing the volume reduction caused by vertical loading, consolidation tests according to ASTM D 2435 (2011) were performed to silty fine zeolite with particles smaller than $0.075 \mathrm{~mm}$. Two samples, C1 and $\mathrm{C} 2$, were prepared with dry unit weights of 9.71 and $11.03 \mathrm{kN} / \mathrm{m}^{3}$ corresponding to 78 and $88 \%$ of the maximum Proctor compaction dry unit weight. Figure 5 shows the consolidation curves for both samples and Tables $3 a, b, c$ summarises results obtained from the oedometric tests. It is worth highlighting that several of the soil parameter values depend on the stress level, in particular the compressibility by means of the constrained modulus.

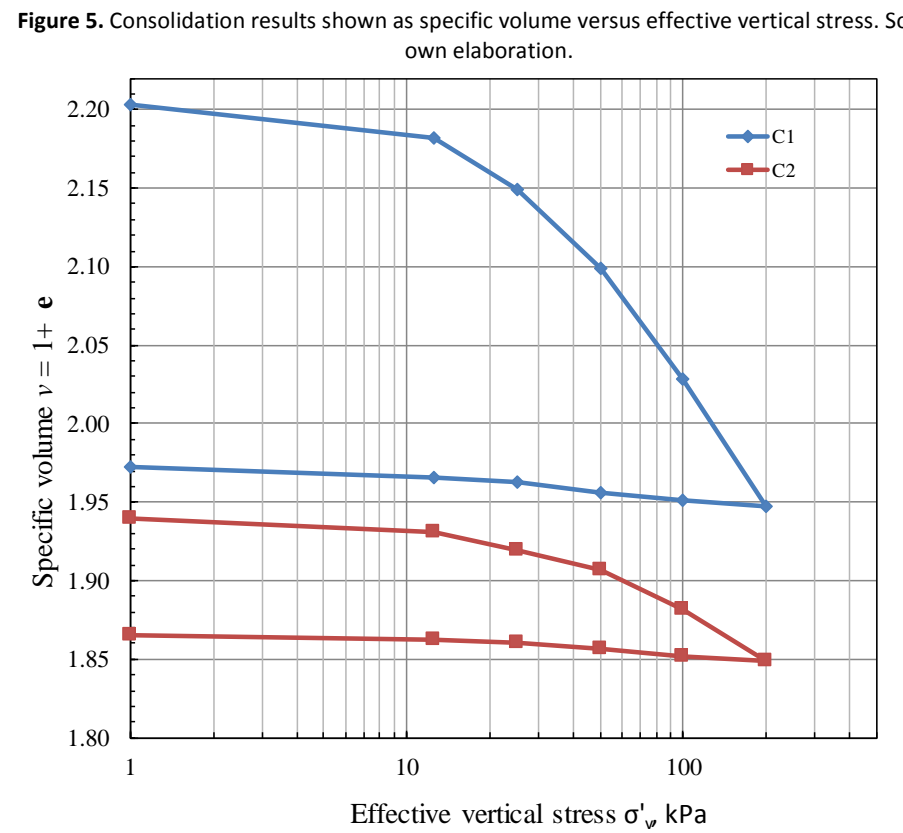


Table 3a. Consolidation test results for samples $\mathrm{C} 1$ and $\mathrm{C} 2$ in loading. Source: own elaboration.

\begin{tabular}{|c|c|c|c|c|c|}
\hline Loading, kPa & $0-12.5$ & $12.5-25$ & $25-50$ & $50-100$ & $100-200$ \\
\hline$\sigma_{\mathrm{v}, \mathrm{kPa}}^{\prime}$ & 12.5 & 25 & 50 & 100 & 200 \\
\hline$\Delta \sigma_{\mathrm{v}}^{\prime}, \mathrm{kPa}$ & 12.5 & 12.5 & 25 & 50 & 100 \\
\hline$V_{\mathrm{C} 1}$ & 2.182 & 2.149 & 2.099 & 2.029 & 1.948 \\
\hline$V \subset 2$ & 1.931 & 1.919 & 1.907 & 1.881 & 1.849 \\
\hline$C_{\mathrm{vC} 1}, \mathrm{~cm}^{2} / \mathrm{s} 10^{-5}$ & 5.17 & 2.34 & 5.04 & 6.17 & 7.72 \\
\hline$C_{\mathrm{vC} 2}, \mathrm{~cm}^{2} / \mathrm{s} 10^{-5}$ & 14.2 & 2.65 & 7.71 & 13.7 & 14.4 \\
\hline$M_{\mathrm{C} 1}, \mathrm{MPa}$ & 1.29 & 0.83 & 1.06 & 1.49 & 2.50 \\
\hline$M_{c 2}, \mathrm{MPa}$ & 2.84 & 1.98 & 3.99 & 3.70 & 5.77 \\
\hline \multicolumn{6}{|c|}{$\begin{array}{l}\sigma_{\mathrm{v}}^{\prime} \text { : effective vertical stress, } \Delta \sigma_{\mathrm{v}}^{\prime} \text { : stress increment, } v_{\mathrm{C} 1} \text { : specific volume for sample } \mathrm{C} 1 \text {, } \\
C_{\mathrm{v}} \text { : coefficient of consolidation, } M \text { : constrained modulus. }\end{array}$} \\
\hline \multicolumn{6}{|c|}{ Table $3 \mathbf{b}$. Consolidation test results for samples $\mathrm{C} 1$ and $\mathrm{C} 2$ in unloading. Source: own elaboration. } \\
\hline Loading, $\mathrm{kPa}$ & $200-100$ & $100-50$ & $50-25$ & $25-12.5$ & $12.5-0$ \\
\hline$\sigma_{\mathrm{v}, \mathrm{kPa}}$ & 100 & 50 & 25 & 12.5 & 12.5 \\
\hline$\Delta \sigma_{\mathrm{v}}^{\prime}, \mathrm{kPa}$ & -100 & -50 & -25 & -12.5 & 0 \\
\hline$v_{\mathrm{C} 1}$ & 1.951 & 1.956 & 1.963 & 1.966 & 1.972 \\
\hline$V \subset 2$ & 1.852 & 1.856 & 1.861 & 1.862 & 1.866 \\
\hline$C_{\mathrm{vC} 1}, \mathrm{~cm}^{2} / \mathrm{s} 10^{-5}$ & 48 & 108 & 16.4 & 125 & 4.87 \\
\hline$C_{v c 2}, \mathrm{~cm}^{2} / \mathrm{s} 10^{-5}$ & 321 & 35.8 & 51.8 & 2030 & 8150 \\
\hline$M \mathrm{c}_{1}, \mathrm{MPa}$ & 55.22 & 22.13 & 6.72 & 9.28 & 3.72 \\
\hline$M_{\mathrm{c} 2}, \mathrm{MPa}$ & 56.05 & 20.75 & 10.40 & 14.99 & 7.06 \\
\hline
\end{tabular}

Table 3c. Results of parameter values from consolidation tests for samples C1 and C2. Source: own elaboration.

\begin{tabular}{lcc}
\hline Parameter & $\mathrm{C} 1$ & $\mathrm{C} 2$ \\
\hline Compressibility $\lambda$ & 0.1170 & 0.0460 \\
Unloading-reloading $\kappa$ & 0.0048 & 0.0032 \\
Compression index $\mathrm{C}_{\mathrm{c}}$ & 0.2691 & 0.1058 \\
Swelling index $\mathrm{C}_{\mathrm{s}}$ & 0.0110 & 0.0074 \\
Preconsolidation pressure $\sigma_{\mathrm{pc}}^{\prime}, \mathrm{kPa}$ & 30 & 40 \\
Permeability in loading $k, \mathrm{~m} / \mathrm{s}$ & $8.1 \cdot 10^{-11}$ & $2.1 \cdot 10^{-11}$ \\
Permeability in unloading $\mathrm{k}, \mathrm{m} / \mathrm{s}$ & $3.2 \cdot 10^{-11}$ & $7.2 \cdot 10^{-12}$ \\
\hline
\end{tabular}

$\lambda$ : slope of the loading $v-\ln \sigma^{\prime}{ }_{v}$ curve, $\kappa$ : slope of the unloading $v-\ln \sigma^{\prime}{ }_{v}$ curve.

\section{Shear strength}

Shear strength can become a key parameter in several geotechnical applications, therefore a consistent and extensive series of tests can be normally needed. In order to study the shear strength of the zeolite, direct shear tests were performed considering saturated conditions as less favourable and ranges of normal stresses and densities that can cover practical applications. Direct shear tests were carried out following ASTM D 3080 (2011).

\section{Coarse zeolite}

Saturated samples of coarse zeolite were prepared at relative densities RDs of 35,55 and $90 \%$ in a shear box of $100 \times 100 \times 30 \mathrm{~mm}$. These values of chosen RDs represent loose, medium and dense soil conditions which may occur in the field. Constant normal stresses of 12.3, 24.5, 49 and $98.1 \mathrm{kPa}$ were applied during shearing under a horizontal displacement velocity of $0.5 \mathrm{~mm} / \mathrm{min}$. The normal stresses values cover a range from soil depths from around 1 to 10 $\mathrm{m}$ depth and under this velocity drained conditions are expected. Vertical and horizontal displacements were measured 
electronically using LVDTs (linear variable differential transducer) of $0.001 \mathrm{~mm}$ of resolution. The shear horizontal load was measured using an electronic load cell of $5 \mathrm{kN}$ with $1 \mathrm{~N}$ resolution.

Results from 11 tests are shown in Figure 6 in terms of shear stress $\tau$ versus horizontal displacement $u$ for different vertical normal stresses $\sigma_{\mathrm{n}}$ in the shear plane induced in the middle of the sample and three different RDs. In Figure 6 it is clear to observe the increase of $\tau$ with $\sigma_{n}$ and $R D$, which represent typical response of granular soils. Figure 7 shows the variation of the vertical displacement $w$, as a function of $u$ for the tests shown in Figure 6 . The maximum angle of dilation $\psi$ is also shown in Figure 7, determined as the Arctan of the maximum positive and constant increase of $\delta w / \delta u$. It is clear to observe the increase of zeolite tendency to dilate with RD, although it can be noted that the dilation reduces with the increase of $\sigma_{\mathrm{n}}$. Moreover, the 35\% RD samples dilate only after a contraction and lateral movement between 0.07 and $0.25 \mathrm{~mm}$ and 1.5 and $3 \mathrm{~mm}$, respectively (for $\psi \leq 4^{\circ}$ ). For the $55 \%$ RD samples less contraction occur $(\leq 0.2$ $\mathrm{mm}$ ) and even almost no contraction is measured for $\sigma_{n} \leq 24.5 \mathrm{kPa}$, reaching $5.5^{\circ} \leq \psi \leq 12.7^{\circ}$. Moreover, less contraction and more dilation was measured for the $90 \%$ RD coarse zeolite samples, reaching high values of $\psi$ between $9.9^{\circ}$ and $19.6^{\circ}$. This implies that when large lateral displacements take place, sample density controls the dilative/contractive zeolite response followed by the normal stress level opposite effect.

In Figure 6 it can be noticed that for each normal stress curves tend to end to a constant value of shear stress and converge for large values of $u$ despite the initial significant differences in RD values. Moreover, in the plots of Figure 7 , curves also tend to reach a constant value of $w$ for large values of $u$. This type of soil response is known as critical state, which represent a condition where the soil is not suffering contraction neither dilation under large shear strains without volume change, in this case without vertical displacement. This soil mechanics phenomenon has been studied in many granular soils, however, it has not been reported in zeolite.

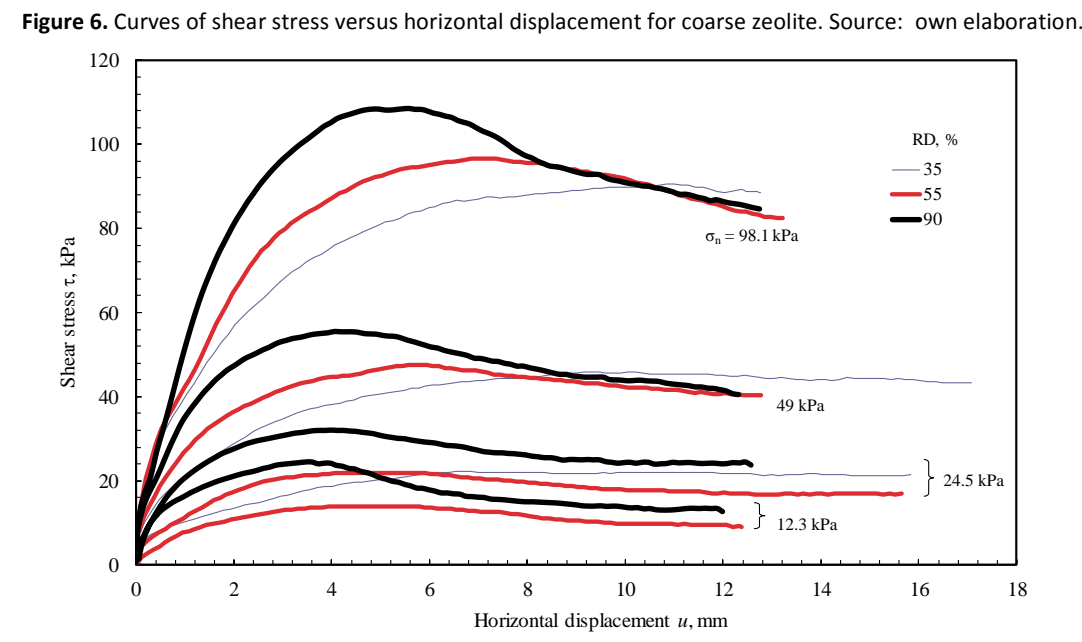

Figure 7. Curves of vertical displacement versus horizontal displacement for different normal stresses, showing the maximum angle of dilation, a) RD $=35 \%$, $b$ ) $55 \%$ and c) $90 \%$. Source: own elaboration.

a)

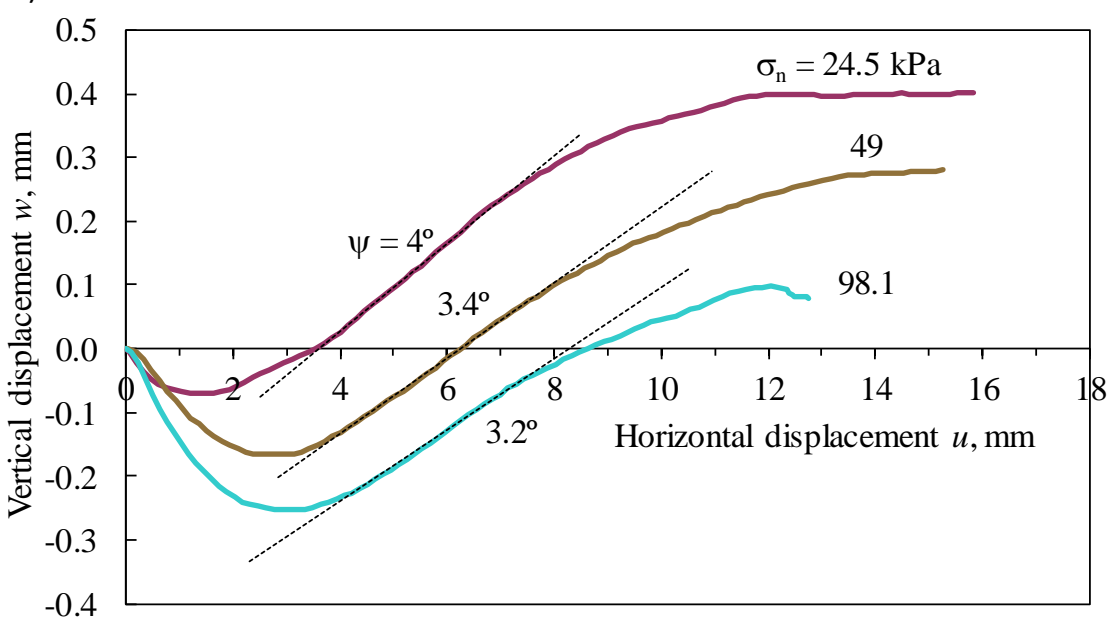


b)

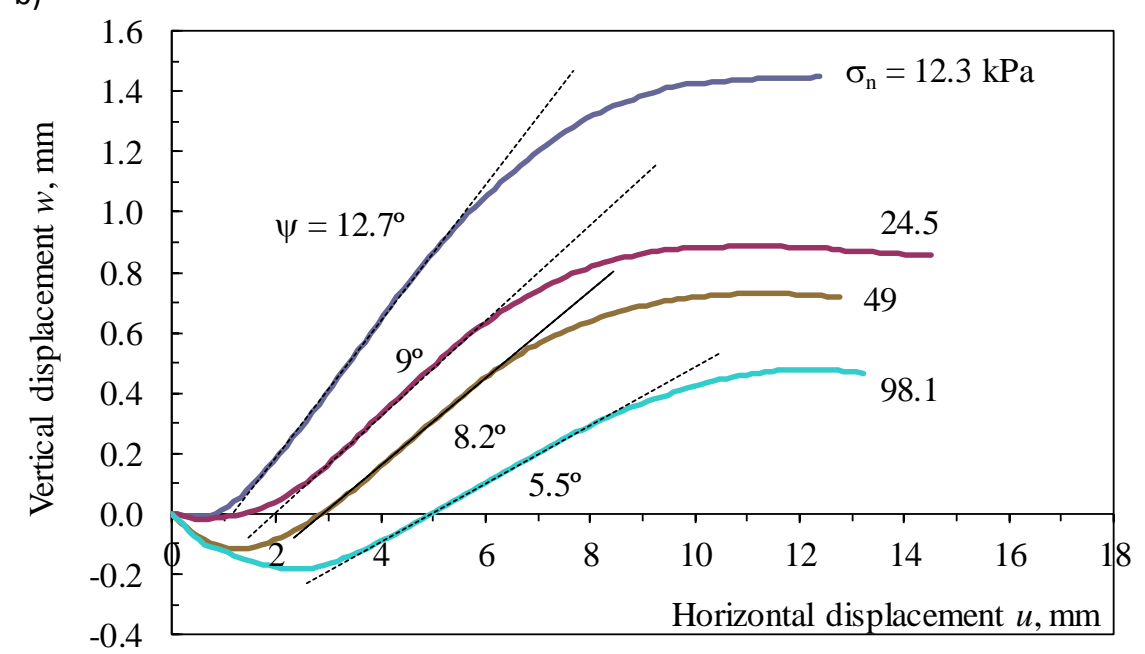

c)

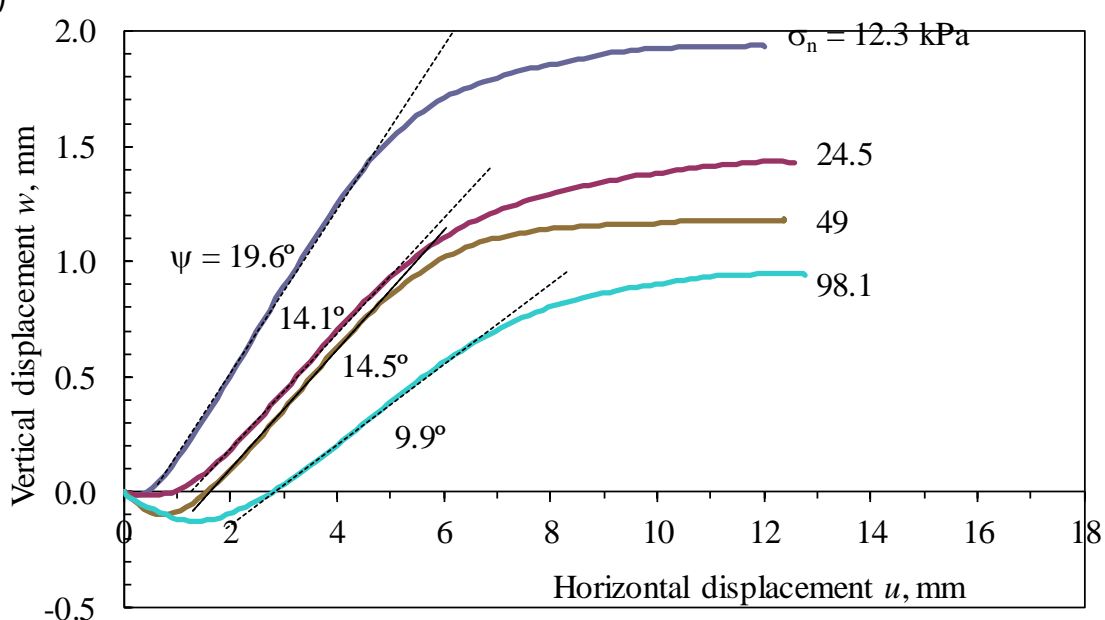

The results of maximum shear stress $\tau_{\max }$ linked to $\sigma_{\mathrm{n}}$ and $\mathrm{RD}$ are plotted as points in Figure 8 . These points show a linear variation which can therefore be fitted using the Coulomb failure criterion to obtain shear strength parameter values (cohesion $c$ and angle of friction $\phi$ ) for the coarse zeolite. In addition to $\tau_{\max }$, Figure 8 also shows points related to the residual shear strength $\tau_{\text {res, }}$ which is close to $\tau_{\max }$ for loose samples, however, they separate for denser samples $(\mathrm{RD}=$ 55 and $90 \%$ ). Note that the quality of data fit is $\mathrm{R}^{2}>0.99$. Moreover, for $\mathrm{RD}=90 \%$ as shown in Figure $8 \mathrm{c}$, it can be observed that cohesion, although small, it is higher than zero. This may be due to the bond developed by the higher packing, i.e. particles are much closer to each other.

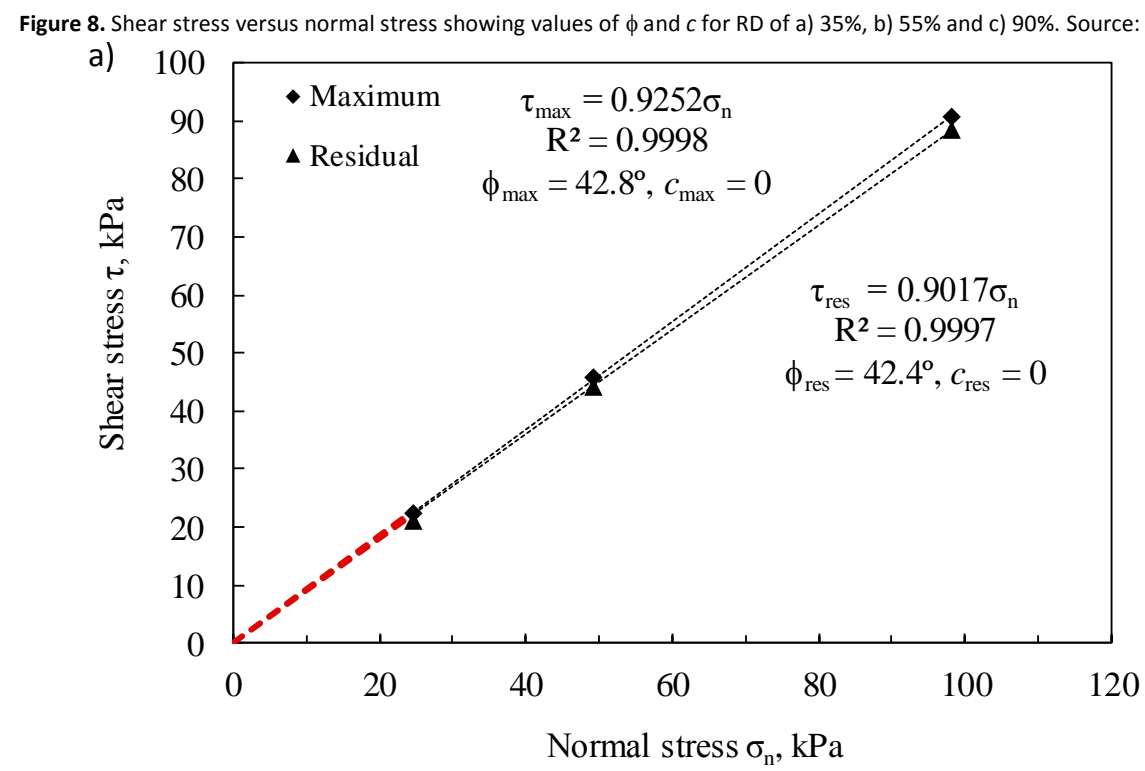



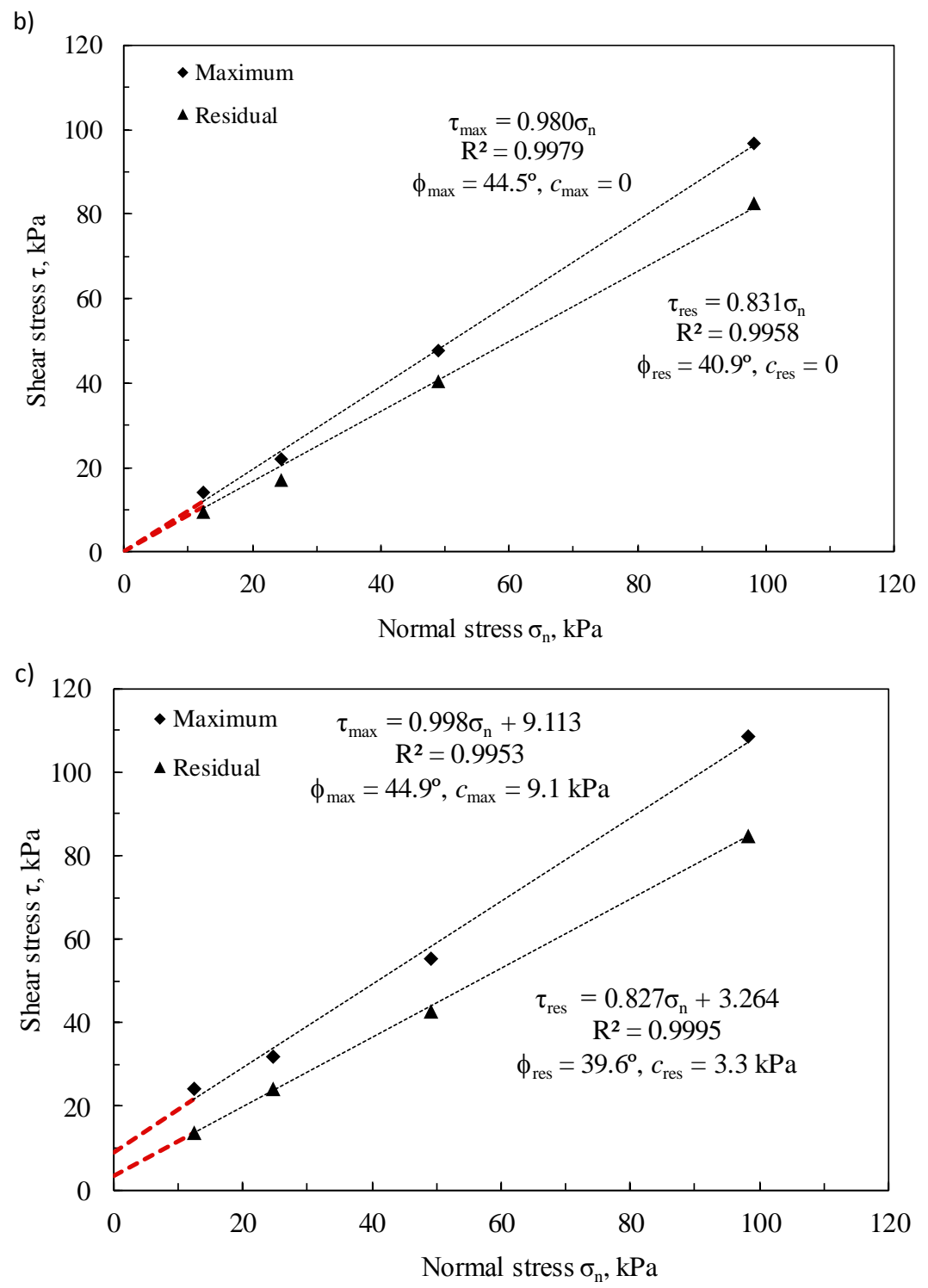

It is worth mentioning that the maximum and residual angles of friction and the cohesion are for drained conditions. The curves in Figure 7 show that for large horizontal displacements the vertical displacement variation is almost zero, independently of the initial RD and $\sigma_{\mathrm{n}}$. Large shear deformations under constant volume (constant vertical displacement) and constant vertical stress is assumed as a steady or critical state. Figure 9 shows the variation of the angle of friction with the horizontal displacement, where it can be observed that for large displacements the curves tend to converge to a common trend (except two curves with $\mathrm{RD}=55 \%$ and $\sigma_{n}=12.5$ and $25 \mathrm{kPa}$ ). According to these results the critical angle of friction converges to a value around $40^{\circ}$.

When plotting the data of $\phi_{\max }$ versus $\psi_{\max }$, it can be observed that the trend of these data follows relatively well the friction-dilation relationship presented by Bolton (1986), as shown in Figure 10, where only one point deviates far from the trend (the one with the largest dilation). This outlier point was caused by a very large maximum shear stress which was double the normal stress. 

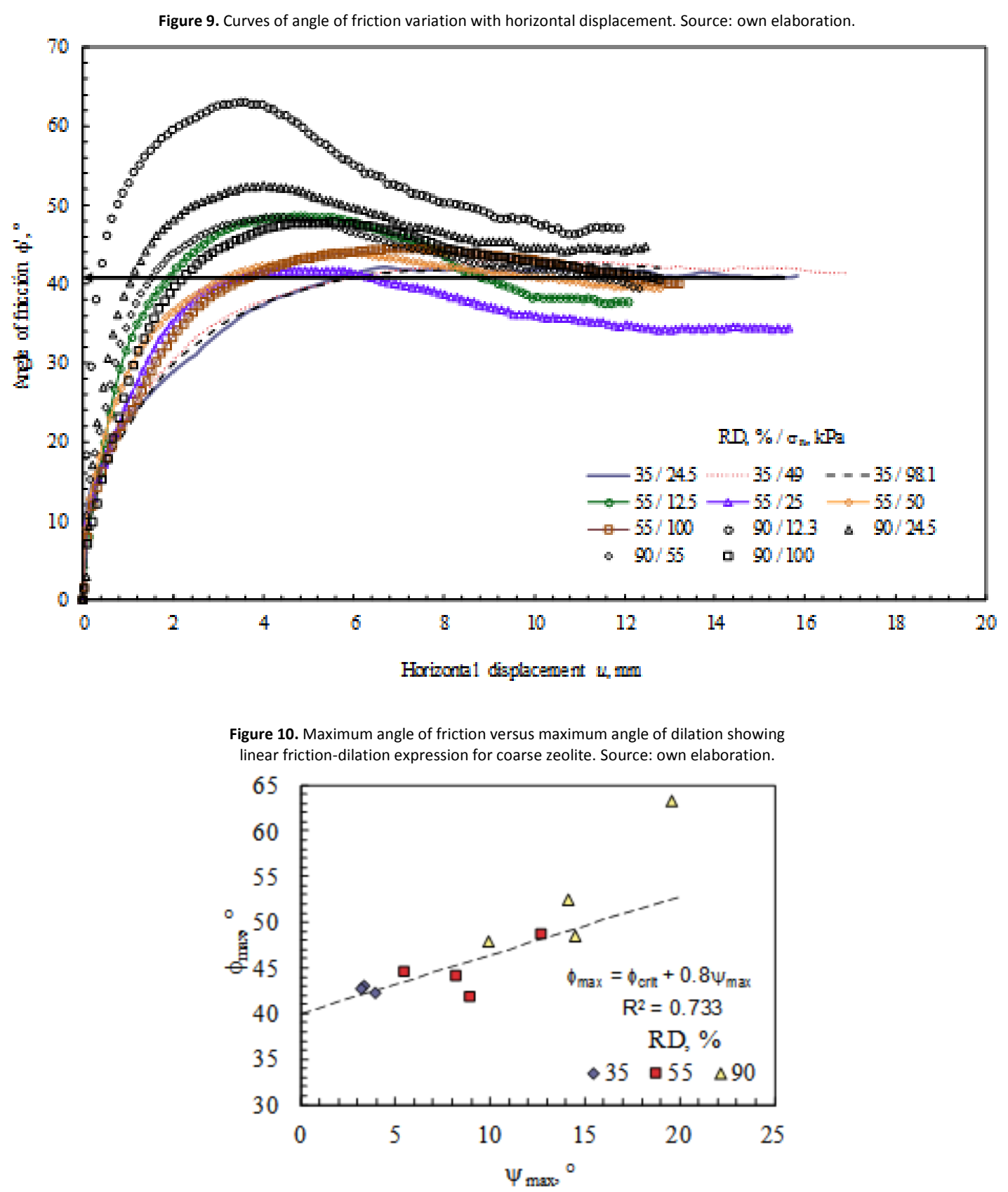

\section{Fine sandy zeolite}

Direct shear tests were also performed with samples of saturated fine sandy zeolite prepared with unit weights equivalent to 75,85 and $90 \%$ of the maximum dry unit weight obtained in the modified Proctor tests. Shearing was undertaken at a velocity of $0.5 \mathrm{~mm} / \mathrm{min}$. Figure 11 shows that despite the increasing level of compaction, there is not a significant increase in shear stress and maximum values of shear stress are lower than for coarse zeolite for similar normal stresses. There are not pronounced peaks of shear stress and hence no clear presence of residual stresses. From the vertical and horizontal displacement curves plotted in Figure 12, it can be observed that compression prevails over dilation, which is the opposite compared with the volumetric response of the coarse zeolite.

The plot in Figure 13 of shear and normal stress does not show a clear separation between the maximum and residual shear stress values and not either for the three unit weights. Table 4 summarises the results of cohesion and angle of friction, where it can be noticed a slight increase of the shear strength parameters with the unit weight. 
Figure 11. Shear stress versus horizontal displacement of fine sand zeolite. Source: own elaboration.

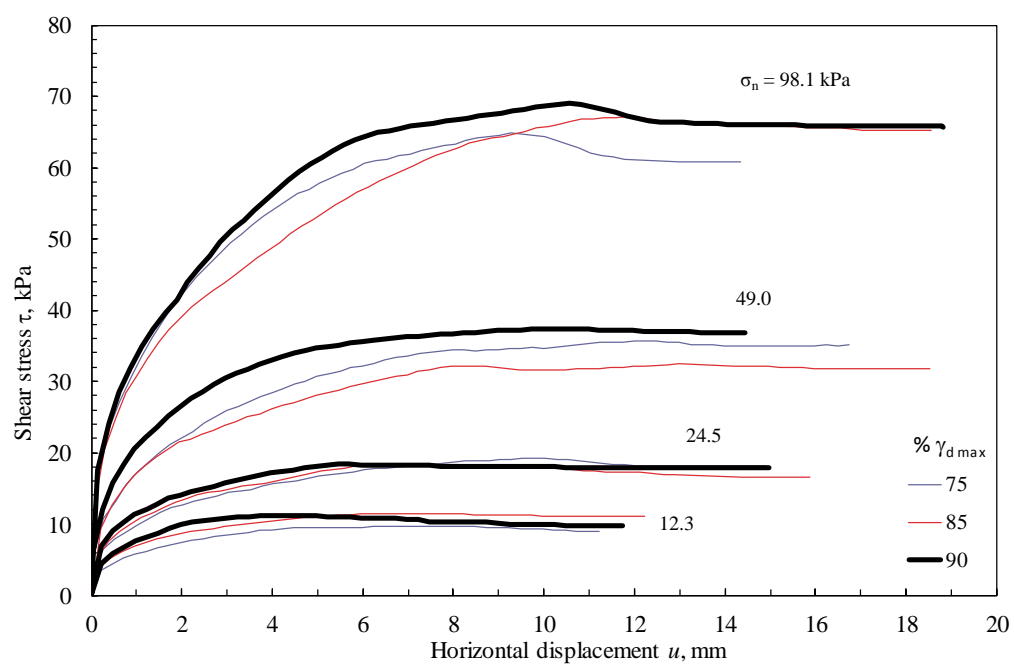

Figure 12. Curves of vertical displacement versus horizontal displacement for different normal stresses and unit weights (\% of $\left.\gamma_{d m a x}\right)$. Source: own elaboration.

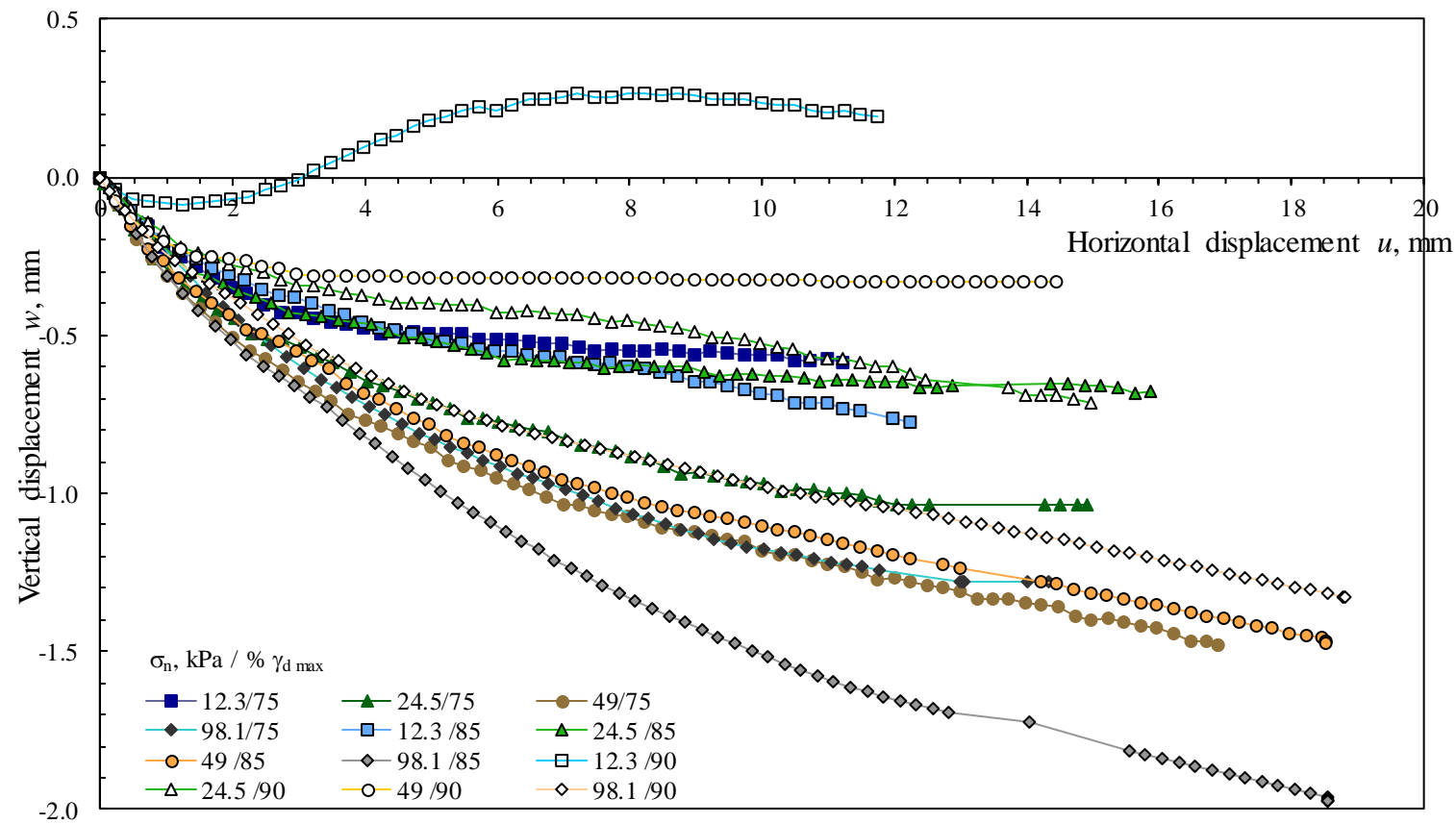

Figure 13. Shear stress versus normal stress showing shear strength maximum and residual values for different percentage of maximum dry unit weights- Source: own elaboration.

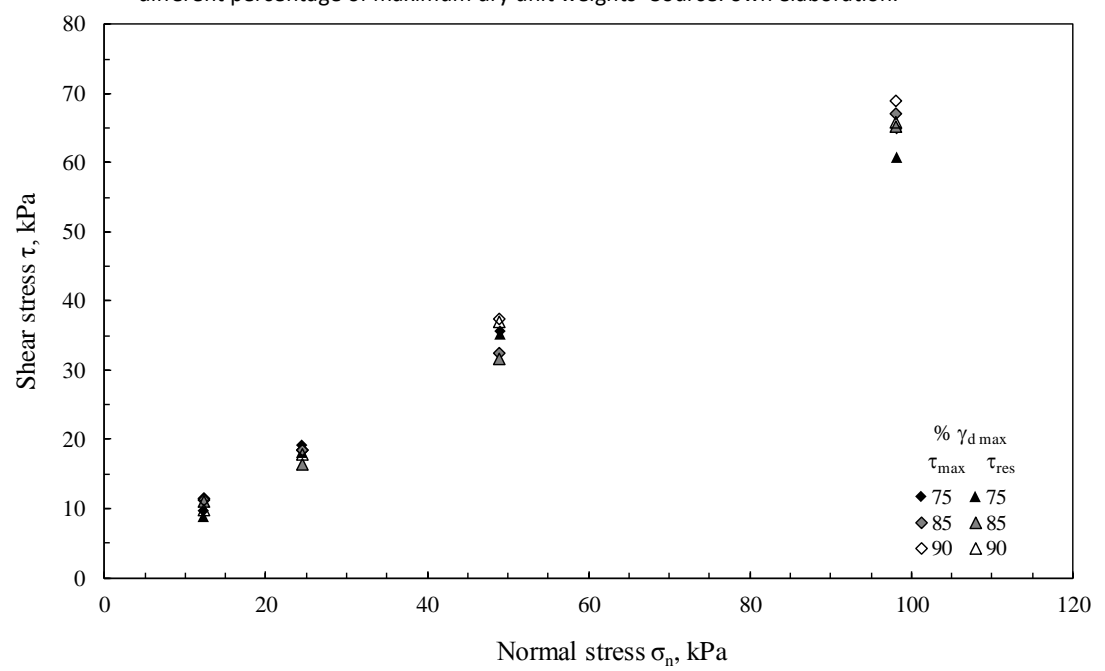


Table 4. Results from direct shear tests using fine sandy zeolite. Source: own elaboration.

\begin{tabular}{cccccc}
\hline$\% \gamma_{d \max }$ & $\gamma_{d}, \mathrm{kN} / \mathrm{m}^{3}$ & $C_{\text {res, }} \mathrm{kPa}$ & $C_{\max }, \mathrm{kPa}$ & $\phi_{\text {res, }}{ }^{\circ}$ & $\phi_{\max }{ }^{\circ}$ \\
\hline 75 & 8.7 & 3.1 & 3.3 & 30.8 & 32.5 \\
80 & 9.9 & 1.7 & 2.4 & 32.6 & 33.1 \\
90 & 10.4 & 2.5 & 2.7 & 33.2 & 34.2 \\
\hline
\end{tabular}

From the values shown in Table 4 it can be pointed out that there is a clear reduction of the angle of friction compared with those determined for the coarse zeolite. This reduction may be explained by the presence of finer sandy material and especially silty material which although in a small proportion (around 3\%) it can induce an important change in shear strength. Although not yet found in monotonically loaded zeolites, this result is in agreement with previous studies on silt-sand mixtures (Khayat, Ghalandarzadeh \& Jafari, 2014) and on strength of sands with small amounts of silts against static liquefaction (e.g. Yamamuro \& Lade, 1998).

\section{Silty zeolite}

Samples with zeolite particles finer than $0.075 \mathrm{~mm}$ were prepared with the $90 \%$ of the maximum dry unit weight obtained in the modified compaction Proctor test. A circular shear box of $60 \mathrm{~mm}$ in diameter and $30 \mathrm{~mm}$ height was used. In order to evaluate the effect of displacement rate on shear strength response, saturated silty zeolite samples were tested under a velocity of $0.06 \mathrm{~mm} / \mathrm{min}$ and other similar samples were tested under a velocity of $0.5 \mathrm{~mm} / \mathrm{min}$. It can be postulated that the former corresponds to drained conditions and the latter to partially drained close to undrained conditions. Although no transducers were used to measure water pore pressures to verify drainage conditions. Figure 14 shows curves of shear stress versus horizontal displacement under different normal stresses and velocities. It is worth observing the significant difference in these curves due to the different velocity of shearing. A stiffer response and a peak shear stress occur when shearing is faster, whilst a monotonic increase of shear strength with horizontal displacement results for the slower tests. Moreover, shear stress of the slow tests under $\sigma_{n}=52$ and $104 \mathrm{kPa}$ tend to reach the fast tests with the same $\sigma_{\mathrm{n}}$ at the end of softening. In Figure 15 the slow test curves show a slight tendency to dilate, whereas a significant contraction can be observed in the fast test curves without reaching a constant vertical to horizontal displacement ratio. An estimation of the shear strength parameter $\phi$ and $c$, is presented in Figure 16, when the lineal Coulomb failure criterion is applied to the maximum and residual values of shear and normal stress. For this fine material made of silt and clay particles there is a further reduction in friction compared with the previous values found for coarse and fine sand type zeolite. Moreover, these values of $\phi_{\max }$ are around a half than those $\left(\phi_{\max }=34,36.5^{\circ}\right)$ obtained under slow rates by Yukselen (2010) for zeolites composed of $12,52.5$, 35.5\% (sand, silt, clay) and $1,67,32 \%$, respectively. On one hand, the slow tests show a similar friction for maximum and residual conditions, but a lower cohesion for the residual case. On the other hand, the fast tests resulted in higher friction, however the cohesion reduced to zero and no residual condition was reached. These results indicate the importance of the displacement rate applied during shearing because they can affect significantly the stiffness and strength measured, in particular in materials with fine particles. Previous studies although in sand also point out that high strain rates result in larger shear strength due to the tendency to dilation caused by the decrease of pore pressure and even generation of negative pore pressure (Yamamuro \& Lade, 1993). Furthermore, in cohesive and non-cohesive soils previous studies have shown that the strength increase due to higher strain rates can be related to soil viscosity (e.g. Locat $\&$ Demers, 1988; Sorensen, Baudet \& Simpson, 2007; Mendoza, Farias \& da Cunha, 2014). Then, further research is needed to study displacement rate effects assessing soil viscosity. In order to determine the zeolite viscosity additional tests are required. 


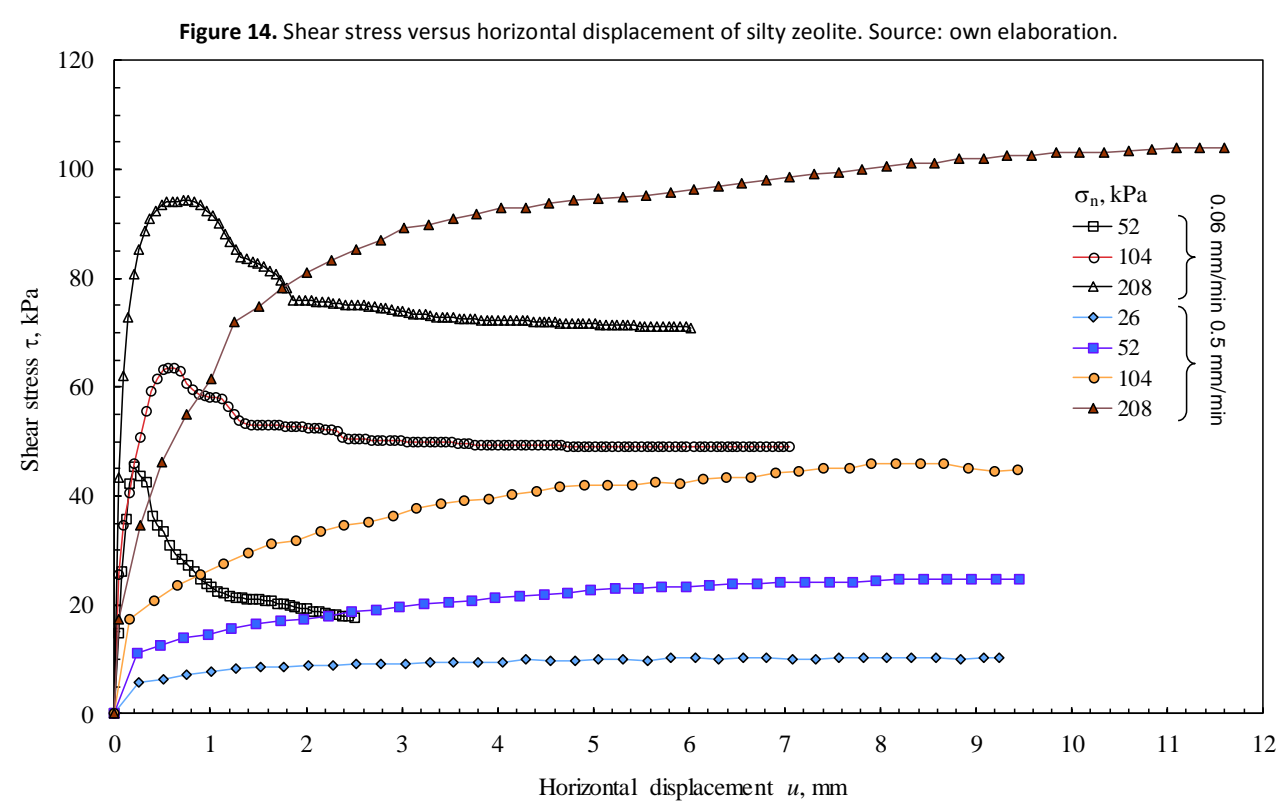

Figure 15. Curves of vertical displacement versus horizontal displacement for different normal stress and loading rate. Source: own elaboration.

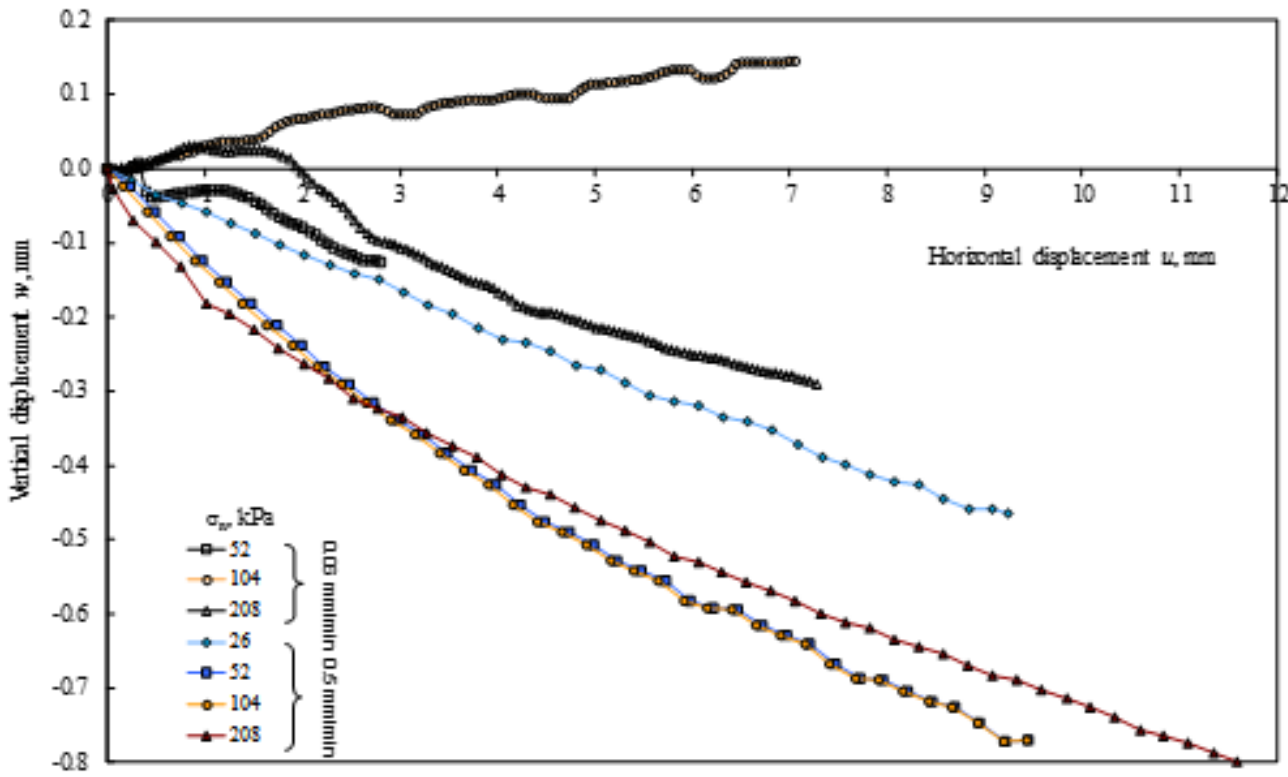

Figure 16. Shear stress versus normal stress showing shear strength maximum and residual values for different displacement rates. Source: own elaboration.

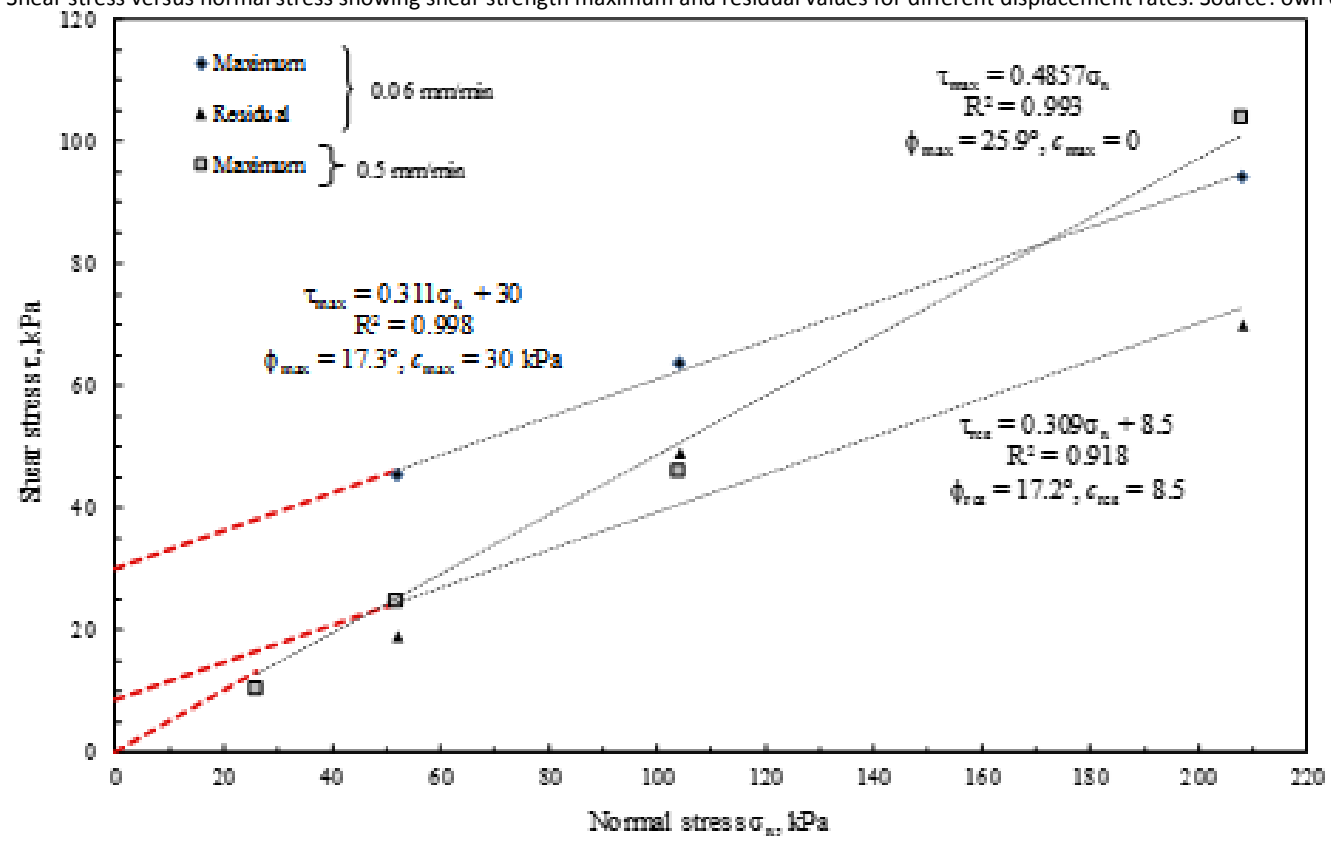


A geotechnical study focused mainly on the fine content effect on the shear strength of a natural zeolite, was presented. The zeolite is from the Colbun Formation and was extracted from a quarry of volcanic tuff in Quinamavida, Chile. According to X-ray diffraction results, the zeolite studied has significant presence of mordenite and clinoptilolite. Three groups of samples were prepared, namely coarse, fine and silty zeolite. Grain size distributions, plasticity index and USCS classifications were determined according to standards. From pycnometer tests it was determined a low value of the specific gravity $\mathrm{G}_{\mathrm{s}}=2.18$, which can explain the also low values of maximum dry unit weight $\gamma_{d m a x}$, between 10.6 and $12.5 \mathrm{kN} / \mathrm{m}^{3}$, obtained in standard vibration and compaction tests. Zeolite shear strength was studied by means of a series of direct shear tests under a combination of loose, medium and dense samples with a normal stress varying from 12.5 to $100 \mathrm{kPa}$. For coarse zeolite the shear stress increased with normal stress and relative density and the dilative/contractive response was similar to that found in granular materials. The coarse zeolite reached a critical state for large displacements, with a value of critical angle of friction tending to $40^{\circ}$. Results of maximum angle of friction and maximum angle of dilation followed relatively well the relation proposed by Bolton (1986) mainly for feldspathic and quartz sands. From similar direct shear tests, zeolite samples with finer sandy material and $3 \%$ of silt had an important reduction in shear strength. Moreover, results showed that there was an almost absence of dilation and residual strength. Finally, tests with zeolite made of $85 \%$ silty and $15 \%$ clayed particles were carried out under slow and fast displacement rates, resulting in the lowest values of angle of friction, in particular for the slow tests. It can be concluded that the presence of fine material can significantly change the shear strength of tuff zeolites tested. A possible explanation for this conclusion may be attributed to the zeolite chemical structure, which allows the storage of large amounts of water. Although for the coarse samples this condition seems to not affect the strength, when finer particles are added the zeolite mechanical response becomes controlled by these fine particles. It is believed that finer particles retain more water than coarse particles, therefore friction is reduced since water cannot withstand shear stresses. Further research is needed to verify chemical effects on the zeolite mechanical response.

\section{References}

Alonso, A., Tejeda, E., Moreno, F., Rubio, M.C. \& Medel, E. (2013). A comparative study of natural zeolite and synthetic zeolite as an additive in warm asphalt mixes. Materiales de Construcción, 63(310), 195-217.

ASTM D 422 (2007). Standard test method for particle-size analysis of soils. West Conshohocken PA, USA.

ASTM D 854 (2014). Standard test methods for specific gravity of soil solids by water pycnometer. West Conshohocken PA, USA.

ASTM D 1557 (2012). Standard test methods for laboratory compaction characteristics of soil using modified effort (56000 ft-lbf/ft ${ }^{3}\left(2700 \mathrm{kN}-\mathrm{m} / \mathrm{m}^{3}\right)$. West Conshohocken PA, USA.

ASTM D 2435 (2011). Standard test methods for one-dimensional consolidation properties of soils using incremental loading. West Conshohocken PA, USA.

ASTM D 2487 (2011). Standard practice for classification of soils for engineering purposes (United Soil Classification System). West Conshohocken PA, USA.

ASTM D 3080 (2011). Standard test method for direct shear test of soils under consolidated drained conditions. West Conshohocken PA, USA. ASTM D 4318 (2010). Standard test methods for Liquid Limit, Plastic Limit and Plasticity Index of soils. West Conshohocken PA, USA.

ASTM D 4253 (2006). Standard test methods for maximum index density and unit weight of soils using a vibratory table. West Conshohocken PA, USA.

ASTM D 4254 (2006). Standard test methods for minimum index density and unit weight of soils and calculation of relative density. West Conshohocken PA, USA.

ASTM D 4972 (2013). Standard test method for pH of soils. West Conshohocken PA, USA.

Bascuñán, S.E. (2005). Geología y mineralogía de las tobas de Quinamavida, Colbún VII Región, Chile. Memoria para optar al título de Geólogo, Universidad de Concepción, Concepción, Chile.

Bolton, M.D. (1986). The strength and dilatancy of sands. Géotechnique, 36(1), 65-78.

BS 1377 1990. Methods of test for soils for civil engineering purposes. Part 2: Classification tests. British Standards Institution, Milton Keynes, UK.

Canpolat, F., Yılmaz, K., Köse, M.M, Sümer, M. \& Yurdusev, M.A. (2004). Use of zeolite, coal bottom ash and fly ash as replacement materials in cement production. Cement and Concrete Research, 34, 731-735.

de la Cruz, J.C., del Campo, J. M., \& Colorado, D. (2015). Comparative study on porosity and permeability of conventional concrete and concrete with variable proportions of natural zeolite additions. Revista de La Construcción, 14(3), 72-78

Hong, C.S., Shackelford, Ch.D. \& Malusis, M.A. (2012). Consolidation and Hydraulic Conductivity of Zeolite-Amended Soil-Bentonite Backfills. Journal of Geotechnical and Geoenvironmental Engineering, 138(1), 15-25.

Janotka, I. \& Mojumdar, S.C. (2003). Hydration of Portland cement, natural zeolite mortar in water and sulphate solution. Materiales de Construcción, 53(269), 17-27.

Jegandan, S., Liska, M., A. Osman, A-M. \& Al-Tabbaa A. (2010). Sustainable binders for soil stabilization. Proceedings of the ICE - Ground Improvement, 163(1), 53-61.

Karzulovic, J., Hauser, A. \& Vergara, M. (1979). Edades K/Ar en rocas volcánicas intrusivas del área de los proyectos hidroeléctricos ColbúnMachicura-Melado, ENDESA. I/ Congreso Geológico Chileno (Vol. 4, pp. 127-135), Arica, Chile.

Kayabali, K. (1997). Engineering aspects of a novel landfill liner material: bentonite-amended natural zeolite. Engineering Geology, 46(2), 105-114

Kayabali, K. \& Kezer, H. (1998). Testing the ability of bentonite-amended natural zeolite (clinoptinolite) to remove heavy metals from liquid waste. Environmental Geology, 31(2/3), 95-102. 
Khayat, N., Ghalandarzadeh, A. \& Jafari, M.K. (2014). Grain shape effect on the anisotropic behaviour of silt-sand mixtures. Proceedings ICEGeotechnical Engineering, 167(3), 281-296.

Leroueil, S., \& Le Bihan, J. (1996). Liquid limits and fall cones. Canadian Geotechnical Journal, 33(5), 793-798

Locat, J. \& Demers, D. (1988). Viscosity, yield stress, remolded strength, and liquidity index relationships for sensitive clays. Canadian Geotechnical Journal, 25(4), 799-806.

Mendoza, C., Farias, M. \& da Cunha, R.P. (2014). Validación de modelos constitutivos avanzados de comportamiento mecánico para la arcilla estructurada de Brasilia. Obras y Proyectos, 15, 52-70.

Mier, M.V., Callejas, R.L., Gehr, R., Cisneros, B.E.J. \& Alvarez, P.J.J. (2001). Heavy metal removal with Mexican clinoptilolite: multi-component ionic exchange. Water Research, 35, 373-378.

Ören, A.H. \& Kaya, A. (2014). Compaction and volumetric shrinkage of bentonitic mixtures. Proceedings of the ICE-Geotechnical Engineering, 167(1), 51-61.

Raggiotti, B.B., Positieri, M.J., Locati, F., Murra, J. \& Marfil, S. (2015). Zeolite, study of aptitude as a natural pozzolan applied to structural concrete. Revista de la Construcción, 14(2), 14-20.

Ramirez, R., Chagoyén, E. \& Martirena, J.F. (2017). Caracterización de cambios de volumen en hormigones producidos en Cuba y sus aplicaciones. Obras y Proyectos, 22, 18-30

Sorensen, K.K., Baudet, B.A. \& Simpson, B. (2007). Influence of structure on the time-dependent behaviour of a stiff sedimentary clay. Géotechnique, 57(1), 113-124.

Yamamuro, J. \& Lade, P. (1998). Steady-state concepts and static liquefaction of silty sands. Journal of Geotechnical Geoenvironmental Engineering, $124(9), 868-877$

Yamamuro, J. \& Lade, P. (1993). Effects of strain rate on instability of granular soils. Geotechnical Testing Journal, 16(3), $304-3013$.

Yukselen, Y. (2010). Characterization of two natural zeolites for geotechnical and geoenvironmental applications. Applied Clay Science, 50, $130-136$. 